\title{
Contribution to the Biology of the Spotted Wolffish (Anarhichas minor) in the Northwest Atlantic
}

\author{
Wilfred Templeman \\ Science Branch, Department of Fisheries and Oceans \\ Northwest Atlantic Fisheries Centre, P. C. Box 5667 \\ St. John's, Newfoundland, Canada A1C 5X1
}

\begin{abstract}
Data on the biology of the spotted wolffish in the Northwest Atlantic were obtained in 1946-67 during research fishing with otter trawls and longlines. Length frequencies of males and females showed no consistent differences. The longest male was $118 \mathrm{~cm}$ and the longest female was $121 \mathrm{~cm}$. Egg diameters and ovarian weights of mature fish indicated that spawning of most spotted wolffish occurred during or soon after July-August. Sexual maturity of females over most of the area began at sizes of 75-80 cm or larger, but there were indications that maturity may have begun at smaller sizes off West Greenland and on Flemish Cap. Males weighed more than females at the larger sizes. Weights of the larger size-groups in July-September were lower than in other quarters of the year, in agreement with the probable spawning period. The mean vertebral number of 684 spotted wolffish was 77.64 , with the range being 74-80. There were no significant differences in vertebral means throughout the area, although West Greenland and Flemish Cap data showed possibilities of being lower. The dorsal fin-ray mean for 45 specimens was 75.90 , with the range being 74-77. The correlation between dorsal fin-ray and vertebral numbers was highly significant. Invertebrates and fish composed 77 and $23 \%$ by volume respectively of the stomach contents. Echinoderms, which constituted $52 \%$ of the volume, were the most important prey group.
\end{abstract}

\section{Introduction}

The spotted wolffish (Anarhichas minor) is rare in the Gulf of Maine (NAFO Subarea 5) (Bigelow and Schroeder, 1953) and scarce on the Scotian Shelf (Subarea 4) (Scott, 1982): It is more plentiful in the northern areas off Newfoundland and Labrador (Subareas 3 and 2) (Templeman and Fleming, 1956; Albikovskaya, 1982) and off West Greenland (Subarea 1) (Hansen, 1958; Beese and Kändler, 1969). Little is known of the biology of spotted wolffish in the Northwest Atlantic.

In 1946-67, as opportunity permitted during research vessel cruises that were directed towards investigations of other species, especially cod, haddock and redfish, information was gathered on various biological characteristics of spotted wolffish, including length frequencies, sexual maturity, length-weight relationship, vertebral numbers, dorsal fin-ray numbers and food. Such biological information is useful for comparisons with studies of spotted wolffish from the North Central and Northeast Atlantic by Barsukov (1959), Østvedt (1963), Beese and Kändler (1969), and the studies of wolffish food in the Northwest Atlantic by Albikovskaya (1983) and Templeman (1985). There was the possibility, also, of finding distinctions between areas, which would aid in stock discrimination.

\section{Materials and Methods}

Data on the biology of spotted wolffish in the Northwest Atlantic were gathered usually from samples of catches by research vessels fishing with bottom otter trawls. Data on length, sex, and vertebral numbers were also obtained from bottom catches by research longliners. The distribution of the spotted wolffish samples is shown in Fig. 1. Most were taken between 100 and 200 fathoms (183-366 m). For the analysis of vertebral numbers, Div. $2 \mathrm{~J}$ was divided into $2 \mathrm{Jn}$ and $2 \mathrm{Js}$ at $53^{\circ} 10^{\prime} \mathrm{N}$. This division allowed data from $2 \mathrm{Js}$ to be included with data from the Northeast Newfoundland Shelf (Div. 3K) of which it (2Js) forms a natural part.

Females with ovaries containing yellowish or orange-yellow developing eggs greater than $1.4 \mathrm{~mm}$ in diameter were classed as maturing or mature. Females were also classed as mature when the spent ovaries had a tough, wrinkled appearance and when large residual eggs remained in the ovaries from a previous spawning. Sexual maturities were not determined for males because their relatively small testes made field observations of maturity uncertain.

Total length was measured from the most anterior part of the head, with the mouth closed, to the posterior end of the caudal fin. The gonads of the gutted and gilled fish were removed before weighing. Fish to be weighed on shore were kept in good condition in ice. Shore weights were taken to the nearest $50 \mathrm{~g}$, except for those over $13.6 \mathrm{~kg}$ which were to the nearest $450 \mathrm{~g}$. Weights at sea were usually taken to the nearest 100 or $200 \mathrm{~g}$, but those over $13.6 \mathrm{~kg}$ were taken to the nearest $450 \mathrm{~g}$. Only four fish less than $30 \mathrm{~cm}$ were weighed, and these were not included in the comparisons.

Vertebral counts were made on oven-dried specimens from which the flesh had been removed by steam cooking and cleaning with a water-pressure hose. Dor- 


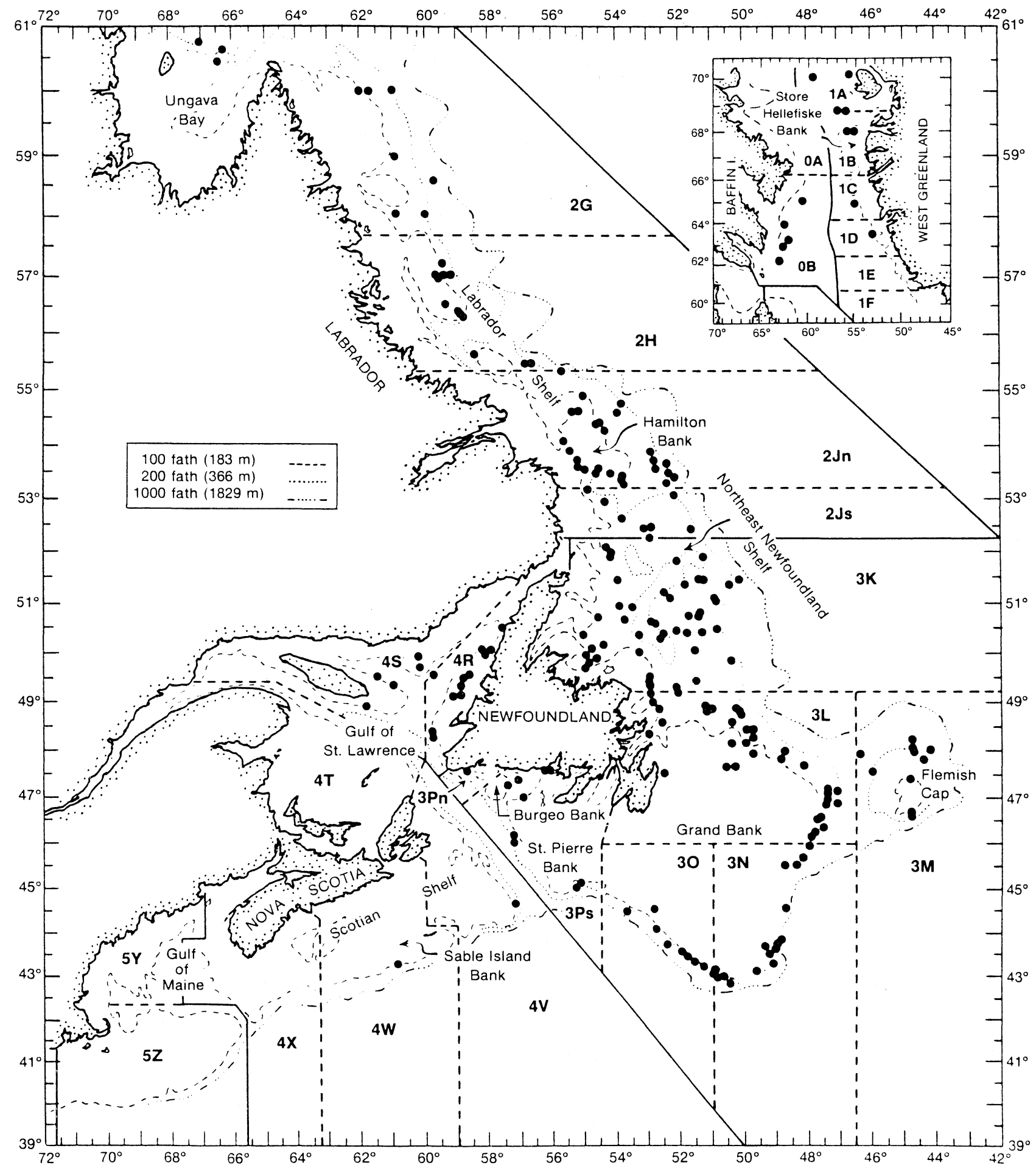

Fig. 1. Place names, NAFO divisions and locations of spotted wolffish samples in the Northwest Atlantic.

sal fin-ray counts were made directly from the fish with the skin peeled from one side of the fin. Vertebral columns with fused vertebrae were not used, and the urostylar half vertebra was included in the count as a vertebra. All wolffish used for dorsal fin-ray and verte- bral counts were $20 \mathrm{~cm}$ or more in total length and were taken during 1950-67.

Stomach contents of the wolffish in field studies were recorded as occurrence or volume $(\mathrm{ml})$ by spe- 
cies, genus or higher taxonomic group.

\section{Results and Discussion}

\section{Length frequencies of catches}

The spotted wolffish taken with longlines were from the slopes of the coastal shelves of Div. $2 \mathrm{~J}, 3 \mathrm{~K}$ and $3 L$ in 1953-54 and show a bimodal distribution for each sex (Fig. 2). Ninety-one percent of the otter-trawl fish were from Div. $2 \mathrm{GHJ}$ and $3 \mathrm{KLMNO}$, and the remainder from other divisions of Subareas 0-4. The otter-trawl frequencies were well distributed over a large part of the period of study, but, nonetheless, the length distribution of females was bimodal and very similar to that from the longline catches. The length frequencies of longline-caught fish showed a lack of females at the greatest lengths. From the otter-trawl catches, both sexes were similar in final size but males were more numerous at lengths above $78 \mathrm{~cm}$. There were few longline fish below $60 \mathrm{~cm}$ and none below $42 \mathrm{~cm}$, in contrast to the composition of otter-trawl catches. The largest male, from Div. 30, was $118 \mathrm{~cm}$ in length and the largest female, from Div. 3Ps, was $121 \mathrm{~cm}$.

McKenzie and Homans (1938) reported a 134-cm spotted wolffish from Sable Island Bank off Nova Scotia. Hansen's (1957) length frequencies of this species off West Greenland show sizes increasing from north to south with maximum lengths slightly over $130 \mathrm{~cm}$. Barsukov (1959) reported that, in the northwestern part

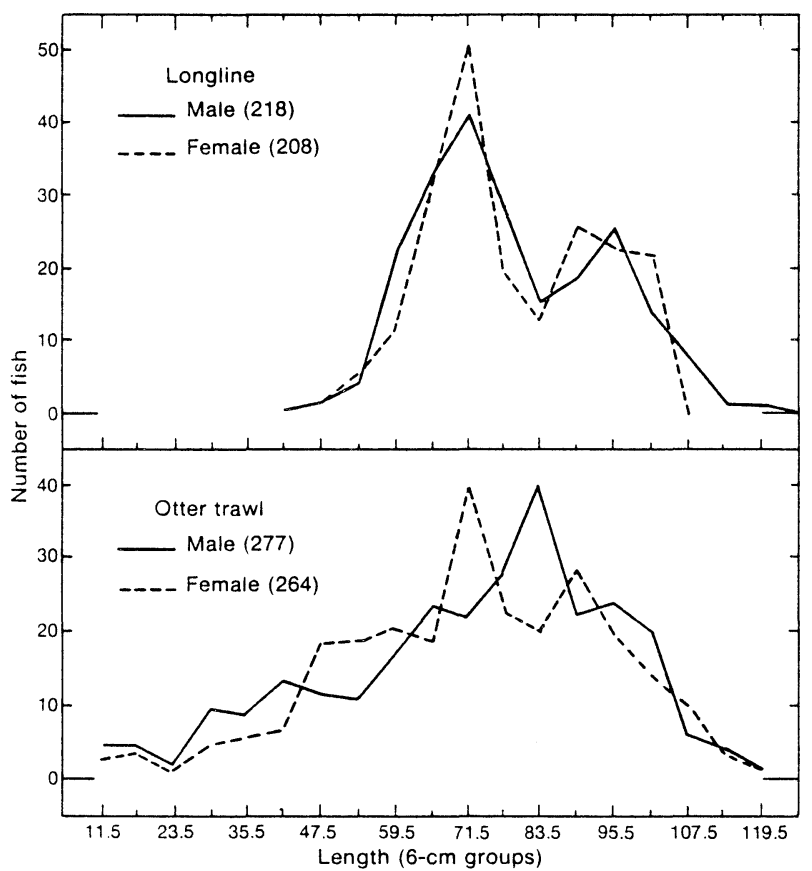

Fig. 2. Length frequencies of spotted wolffish samples caught by longline and otter trawl in the Northwest Atlantic, 1946-67. of the Barents Sea, the maximum sizes of male and female spotted wolffish were 133 and $124 \mathrm{~cm}$ respectively, and, quoting from Knipowitsch (1902), he cited a maximum length of $135 \mathrm{~cm}$ for the Barents Sea. $\emptyset$ stvedt (1963) reported, for Nordbank off northern Norway, maximum lengths of $133-139 \mathrm{~cm}$ for male and $138-143 \mathrm{~cm}$ for female spotted wolffish, but males predominated at the larger sizes and at the greatest ages off northern Norway and at Bear Island. Beese and Kändler (1969) found higher numbers of males than females at the largest sizes in their combined data for Greenland, Iceland and Barents Sea. In Lundbeck's (1937) market mesurements of German catches, the greatest lengths of spotted wolffish were $111-120 \mathrm{~cm}$ from Iceland and $121-131 \mathrm{~cm}$ from the Barents Sea, but, in his length-weight records from these catches, Lundbeck (1952) recorded spotted wolffish of $123 \mathrm{~cm}$ from both Iceland and the Barents Sea.

\section{Size at sexual maturity in females and fecundity}

Length at sexual maturity. Female spotted wolffish began maturing in substantial proportions at lengths of $75-80 \mathrm{~cm}$ and higher, and almost all were mature or maturing at sizes greater than $92 \mathrm{~cm}$ (Table 1). The small numbers of specimens prevented close comparison of lengths at maturity in different areas but indicated the possibility that maturity began earlier off West Greenland (Div. 1ABCD) and on Flemish Cap (Div. 3M) than in other areas. However, it was in these areas that almost all of the smallest maturing and mature specimens at sizes of $80 \mathrm{~cm}$ or less were caught. Area differences in length at the beginning of sexual maturity were not so obviously present for $A$. minor of the Northwest Atlantic as they were for $A$. lupus (Templeman, 1986).

Beese and Kändler (1969) reported that sexually mature female spotted wolffish from the Northeast

TABLE 1. Percentage distribution of maturing and mature female spotted wolffish by length interval in combined samples from the Northwest Atlantic.

\begin{tabular}{cccc}
\hline \hline $\begin{array}{c}\text { Length } \\
\text { interval } \\
(\mathrm{cm})\end{array}$ & $\begin{array}{c}\text { Number } \\
\text { of } \\
\text { females }\end{array}$ & \multicolumn{2}{c}{$\begin{array}{c}\text { Maturing and } \\
\text { mature females }\end{array}$} \\
\cline { 3 - 4 } $21-29$ & 5 & - & Number \\
$30-38$ & 4 & - & - \\
$39-47$ & 12 & - & - \\
$48-56$ & 21 & - & - \\
$57-62$ & 16 & 1 & - \\
$63-68$ & 16 & 1 & 6 \\
$69-74$ & 32 & 4 & 3 \\
$75-80$ & 17 & 6 & 24 \\
$81-86$ & 12 & 11 & 50 \\
$87-92$ & 21 & 14 & 52 \\
$93-98$ & 15 & 15 & 93 \\
$99-104$ & 15 & 8 & 100 \\
$105-110$ & 8 & 3 & 100 \\
$111-116$ & 3 & & 100 \\
\hline
\end{tabular}


Atlantic overlapped the immatures at lengths between 48 and $62 \mathrm{~cm}$. Their criteria for the maturing and mature stages appear to be fairly similar to those of the present paper. Østvedt's (1963) stage II (maturing) for spotted wolffish included fish with both large and small eggs. In this paper, fish with larger eggs were called maturing, and those with smaller eggs which may take a long time to develop were called immature. His stage III (mature or spawning) and stage IV (spent) females from Bear Island were $78-82 \mathrm{~cm}$ and greater in length. Barsukov (1959) recorded maturing female spotted wolffish of $85-120 \mathrm{~cm}$ in length.

Fecundity. The numbers of developing eggs for the next spawning were counted for three spotted wolffish: (a) $65 \mathrm{~cm}$ long, 5,080 eggs, maximum egg diameter $3.5 \mathrm{~mm}$, captured at a depth of $311 \mathrm{~m}$ on Store Hellefiske Bank (Div. 1B) on 8 August 1965; (b) $82 \mathrm{~cm}$ long, 11,970 eggs, maximum egg diameter $3.2 \mathrm{~mm}$, captured at $274 \mathrm{~m}$ on Flemish Cap (Div. 3M) on 22 March 1961; and (c) $91 \mathrm{~cm}$ long, 19,760 eggs, maximum egg diameter $2.5 \mathrm{~mm}$, captured at $552 \mathrm{~m}$ on the southeast slope of Hamilton Bank (Div. 2J) on 4 April 1964. These egg counts were lower at $65 \mathrm{~cm}$ and higher at 82 and $91 \mathrm{~cm}$ than the fecundity results of 12 spotted wolffish specimens from the Northeast Atlantic (Beese and Kändler, 1969).

\section{Spawning time}

Ovarian egg sizes. Fish which were classed as immature, based on the criteria used, had maximum egg diameters in the range of 0.3-1.2 $\mathrm{mm}$ (Table 2). Some individuals, with ovaries containing residual eggs from the previous spawning and with obviously spent ovaries, had new eggs as small as $0.8-1.4 \mathrm{~mm}$ diameter. Fish with ripening eggs for the next spawning (defined as those greater than about $1.4 \mathrm{~mm}$ diameter) occurred in all bimonthly periods. The largest eggs (3.5-5.0 mm diameter) were from July-August samples, including a $103-\mathrm{cm}$ fish from Div. $3 \mathrm{~L}$ on 31 July with maximum egg diameter of $4.5 \mathrm{~mm}$ and a $94-\mathrm{cm}$ fish from Div. $3 \mathrm{~K}$ on 4 August with egg diameter of 5 $\mathrm{mm}$. The latter specimen was ripe and running. There was, however, a female from Flemish Cap with 3.2-mm diameter eggs on 22 March. As many of the small whitish eggs developed and assumed the orangeyellow or yellowish appearance, some of the whitish eggs remained undeveloped at diameters of 0.6-1.1 $\mathrm{mm}$ (i.e. similar to those designated as immature).

Ovarian weight. The ovarian weight, as percentage of gutted and gilled weight of mature fish, exhibited an increase by March-April and was greater in July-August than in September-December (Table 3). There was, however, a female from Flemish Cap with an ovary which was $6.5 \%$ of the gutted and gilled weight in late March.
TABLE 2. Seasonal frequencies of largest non-residual eggs by egg size in ovaries of female spotted wolffish from the Northwest Atlantic. (Numbers in parentheses are ovaries with residual eggs.)

\begin{tabular}{|c|c|c|c|c|c|c|}
\hline \multirow{2}{*}{$\begin{array}{c}\text { Egg } \\
\text { diameter } \\
(\mathrm{mm}) \\
\end{array}$} & \multicolumn{6}{|c|}{ Frequency of observations } \\
\hline & $\begin{array}{l}\text { Jan- } \\
\text { Feb }\end{array}$ & $\begin{array}{l}\text { Mar- } \\
\mathrm{Apr}\end{array}$ & $\begin{array}{l}\text { May- } \\
\text { Jun }\end{array}$ & $\begin{array}{l}\text { Jul- } \\
\text { Aug }\end{array}$ & $\begin{array}{l}\text { Sep- } \\
\text { Oct }\end{array}$ & $\begin{array}{l}\text { Nov- } \\
\text { Dec }\end{array}$ \\
\hline \multicolumn{7}{|c|}{ Immature } \\
\hline $0.3-0.5$ & - & 4 & 2 & 4 & - & 1 \\
\hline $0.6-0.9$ & - & 3 & 6 & 6 & 7 & 3 \\
\hline $1.0-1.2$ & - & 4 & 14 & 8 & 12 & 3 \\
\hline \multicolumn{7}{|c|}{ Doubtful maturity } \\
\hline 0.9 & - & - & - & 1 & - & - \\
\hline $1.0-1.4$ & - & 3 & 2 & 6 & 10 & 10 \\
\hline \multicolumn{7}{|c|}{ Maturing and mature } \\
\hline $0.8-0.9$ & - & - & - & $1(1)$ & - & - \\
\hline $1.0-1.4$ & 1 & $4(2)$ & 3 & $7(2)$ & 2 & $8(8)$ \\
\hline $1.5-1.9$ & - & 1 & - & 5 & $5(1)$ & $10(3)$ \\
\hline $2.0-2.4$ & - & - & - & - & - & $1(1)$ \\
\hline $2.5-2.9$ & $1(1)$ & 1 & $1(1)$ & - & - & $1(1)$ \\
\hline $3.0-3.4$ & - & 1 & - & 1 & - & - \\
\hline $3.5-3.9$ & - & - & - & 2 & - & - \\
\hline $4.0-4.4$ & - & - & - & - & - & - \\
\hline $4.5,5.0$ & - & - & - & 2 & - & - \\
\hline
\end{tabular}

Variation in length-weight relationship relevant to spawning. Preliminary plotting of individual records of of $\log _{10}$ weight $(\mathrm{kg})$ against $\log _{10}$ length $(\mathrm{cm})$, by sex and quarterly period, showed that the length-weight relationship of spotted wolffish could be represented adequately by log-log least squares straight lines. From the equations of these lines, weights at total lengths of 50,75 and $100 \mathrm{~cm}$ were calculated (Table 4).

In nine comparisons between sexes for the same quarterly period, method of weighing and location, males weighed more than females in four cases at 50 $\mathrm{cm}$ fish length, in seven cases at $75 \mathrm{~cm}$, and in all nine comparisons at $100 \mathrm{~cm}$. From covariance analysis (Snedecor and Cochran, 1980), F-values for three of these nine pairs of regression lines indicated significant differences (two for slope, and one for intercept). Males and females at the smaller immature lengths weighed about the same, but there was a tendency for males to weigh more than females at the greater maturing and mature lengths. Sexes were therefore compared separately in the quarterly comparisons.

At $100 \mathrm{~cm}$, representing the mature fish, July-September weights were less than April-June weights in all four comparisons, and F-values of the lengthweight regression lines for these quarters, compared by covariance analysis, were significantly different for the slopes in these comparisons. The July-September weights were less than the October-November weights in five of six comparisons, and F-values of the 
TABLE 3. Seasonal trends in ovary weight, expressed as percentage of gutted and gilled weight, of female spotted wolffish ( $>30 \mathrm{~cm}$ in length) from the Northwest Atlantic.

\begin{tabular}{|c|c|c|c|c|c|c|c|c|c|}
\hline \multirow{3}{*}{$\begin{array}{c}\text { Bimonthly } \\
\text { period }\end{array}$} & \multicolumn{3}{|c|}{ Immature } & \multicolumn{3}{|c|}{ Doubtful maturity } & \multicolumn{3}{|c|}{ Maturing and mature } \\
\hline & \multirow{2}{*}{$\begin{array}{c}\text { No. of } \\
\text { fish }\end{array}$} & \multicolumn{2}{|c|}{$\%$ ovary weight } & \multirow{2}{*}{$\begin{array}{l}\text { No. of } \\
\text { fish }\end{array}$} & \multicolumn{2}{|c|}{$\%$ ovary weight } & \multirow{2}{*}{$\begin{array}{l}\text { No. of } \\
\text { fish }\end{array}$} & \multicolumn{2}{|c|}{$\%$ ovary weight } \\
\hline & & Mean & Range & & Mean & Range & & Mean & Range \\
\hline Mar-Apr & 11 & 0.7 & $0.3-1.3$ & 2 & 1.2 & $1.2-1.2$ & 6 & 3.4 & $1.3-6.5$ \\
\hline May-Jun & 21 & 0.7 & $0.2-1.2$ & 1 & 1.3 & $1.3-1.3$ & 4 & 1.7 & $1.1-2.4$ \\
\hline Jul-Aug & 17 & 0.7 & $0.3-1.4$ & 6 & 1.1 & $0.9-1.3$ & 12 & 4.2 & $0.9-15.7$ \\
\hline Sep-Oct & 18 & 0.6 & $0.3-1.2$ & 3 & 1.3 & $1.1-1.4$ & 8 & 1.3 & $0.7-2.3$ \\
\hline Nov-Dec & 11 & 0.5 & $0.2-0.9$ & 9 & 1.0 & $0.9-1.4$ & 15 & 1.8 & $1.1-2.5$ \\
\hline
\end{tabular}

TABLE 4. Calculated weights from log-log (base 10) weight-length relationships by quarter and sex for spotted wolffish from the Northwest Atlantic, based on length and weight measurements taken on shore and at sea.

\begin{tabular}{|c|c|c|c|c|c|c|}
\hline \multirow[b]{2}{*}{ Sex } & \multirow[b]{2}{*}{ Quarter } & \multirow{2}{*}{$\begin{array}{l}\text { No. } \\
\text { of } \\
\text { fish }\end{array}$} & \multirow{2}{*}{$\begin{array}{l}\text { Length } \\
\text { range } \\
(\mathrm{cm})\end{array}$} & \multicolumn{3}{|c|}{$\begin{array}{l}\text { Calculated weights }(\mathrm{kg}) \text { for } \\
\text { three wolffish lengths }(\mathrm{cm})\end{array}$} \\
\hline & & & & 50 & 75 & 100 \\
\hline \multicolumn{7}{|c|}{ Gutted and gilled weights on shore } \\
\hline \multirow[t]{3}{*}{ Male } & Apr-Jun & 13 & $57-103$ & 0.84 & 3.50 & 9.65 \\
\hline & Jul-Sep & 26 & $44-116$ & 0.98 & 3.64 & 9.21 \\
\hline & Oct-Dec & 34 & $39-110$ & 1.34 & 3.85 & 8.13 \\
\hline \multirow[t]{3}{*}{ Female } & Apr-Jun & 16 & $44-88$ & 0.78 & 3.08 & 8.13 \\
\hline & Jul-Sep & 21 & $45-109$ & 1.09 & 3.44 & 7.79 \\
\hline & Oct-Dec & 34 & $38-111$ & 0.99 & 3.39 & 8.12 \\
\hline \multicolumn{7}{|c|}{ Round weights on shore } \\
\hline \multirow[t]{2}{*}{ Male } & Apr-Jun & 13 & $57-103$ & 1.04 & 4.37 & 12.11 \\
\hline & Jul-Sep & 24 & $57-116$ & 1.32 & 4.65 & 11.34 \\
\hline \multirow[t]{2}{*}{ Female } & Apr-Jun & 15 & $44-92$ & 1.10 & 4.44 & 11.96 \\
\hline & Jul-Sep & 19 & 45-109 & 1.41 & 4.28 & 9.41 \\
\hline \multicolumn{7}{|c|}{ Gutted and gilled weights at sea } \\
\hline \multirow[t]{2}{*}{ Male } & Jul-Sep & 24 & $32-100$ & 0.90 & 3.34 & 8.44 \\
\hline & Oct-Dec & 17 & $37-114$ & 1.04 & 3.65 & 8.90 \\
\hline \multirow[t]{3}{*}{ Female. } & Jan-Mar & 14 & $39-116$ & 0.98 & 3.36 & 8.08 \\
\hline & Jul-Sep & 22 & $34-107$ & 0.93 & 3.22 & 7.79 \\
\hline & Oct-Dec & 21 & $50-111$ & 0.98 & 3.39 & 8.17 \\
\hline \multicolumn{7}{|c|}{ Round weights at sea } \\
\hline \multirow[t]{2}{*}{ Male } & Jul-Sep & 40 & $32-102$ & 1.22 & 4.27 & 10.41 \\
\hline & Oct-Dec & 18 & $35-114$ & 1.35 & 4.69 & 11.33 \\
\hline \multirow[t]{3}{*}{ Female } & Jan-Mar & 15 & $35-116$ & 1.18 & 4.14 & 10.07 \\
\hline & Jul-Sep & 30 & 34-107 & 1.24 & 4.28 & 10.34 \\
\hline & Oct-Dec & 22 & $38-111$ & 1.18 & 4.30 & 10.73 \\
\hline
\end{tabular}

length-weight regression lines for these quarters were highly significant for two of the five intercepts.

At 50 and $75 \mathrm{~cm}$, representing immature and presumably mainly immature fish respectively, there was a progressive increase in weight from April-June to October-December. Weights in July-September were greater than in April-June in seven of eight comparisons, and weights in October-December were greater than in July-September in 10 of 12 comparisons.

It is common for the somatic weight of fish to reach an annual minimum associated with the spawning period (Kohler, 1959). Thus, the observation that the lowest weights of the mature specimens of $A$. minor occur in July-September corresponds with the other evidence that this species spawns in the summer. For A. lupus of the North Atlantic, in agreement with its mainly autumn spawning, the weights at length were lowest in October-December and highest in JulySeptember (Templeman, 1986).

Large catches during or near the spawning period. In August-early September 1972, some Newfoundland otter trawlers landed unusually large quantities of spotted wolffish which were caught on the northwest- 
ern slope of the Grand Bank. The St. John's Evening Telegram on 1 September 1972 reported that otter trawlers from Burin and Marystown, Placentia Bay, Newfoundland, had discharged $410,000 \mathrm{~kg}$ of wolffish during the preceding 10 days, more than has ever been landed before in a similar period of time. As a rule, less than $1,000 \mathrm{~kg}$ of wolffish (Atlantic and spotted) are landed at these ports from a single trip of a vessel with $140,000 \mathrm{~kg}$ of groundfish. These large trawl catches in 1972, some of which are recorded in Table 5, were reported to be spotted wolffish by an experienced fisheries technician from the St. John's Biological Station. Records of large schools of spotted wolffish are unusual and these large catches are particularly noteworthy, because the time of capture was close to the probable spawning season and may have been related to schooling for spawning.

Conclusion. The evidence for mainly summer spawning of spotted wolffish in the Northwest Atlantic is thus from egg sizes, ovarian weights, quarterly length-weight relationships, and possibly from large catches near the spawning period. Although lack of extensive data results in the conclusions from each source separately being weak, the relative agreement from all sources makes it likely that most spawning occurs in summer. This is consistent with observations in other areas. Spotted wolffish off southern Iceland spawn in the late summer months (Lühmann, 1954). $\emptyset$ stvedt (1963) reported that spotted wolffish near Bear
Island spawn in July and that the main spawning season for this species in the Barents Sea is July and probably also August.

\section{Meristic variation}

Vertebral numbers. Vertebral means of spotted wolffish from various divisions of the Northwest Atlantic ranged between 77.27 for Flemish Cap (Div. 3M) and 77.72 for southern Labrador (Div. 2Jn), but there were no significant differences among areas $(P>0.05)$ (Table 6). The means for West Greenland (Div. 1ABC) and for Flemish Cap (Div. 3M) indicated the possibility that they might be significantly lower than those for the other divisions if sample sizes had been larger for the two areas. Differences in vertebral numbers of spotted wolffish between areas in the Northwest Atlantic were not so evident as those demonstrated by Templeman (1984) for the Atlantic wolffish.

The overall vertebral frequency for the Northwest Atlantic was: $74(1) 75(3), 76(37), 77(241), 78(322)$, $79(77), 80(3)$, with mean and standard errors of $77.64+$ 0.03 . This compares with Lühmann's (1954) vertebral average (78.16) and range (77-79) for 45 spotted wolffish from southwestern Iceland. The mean of 75.2 with range of $74-78$ for $A$. minor from the Barents Sea, stated by Barsukov (1959) to be from Lühmann (1954), are not from the latter author, but presumably are Barsukov's data on A. lupus from the Barents Sea, mis-

TABLE 5. Some catches of spotted wolffish (from captain's estimates in logbooks) on the northwestern slope of Grand Bank in August-early September 1972 by Newfoundland trawlers landing at Burin and Marystown. Placentia Bay.

\begin{tabular}{|c|c|c|c|c|c|}
\hline \multirow{2}{*}{$\begin{array}{l}\text { Trip dates } \\
\text { of trawlers }\end{array}$} & \multicolumn{2}{|c|}{ Fishing area } & \multirow{2}{*}{$\begin{array}{l}\text { Depth } \\
\text { (m) }\end{array}$} & \multirow{2}{*}{$\begin{array}{c}\text { Fishing } \\
\text { days }\end{array}$} & \multirow{2}{*}{$\begin{array}{l}\text { Catch } \\
(\mathrm{kg})\end{array}$} \\
\hline & Lat. & Long. & & & \\
\hline $11-22$ Aug & $48^{\circ}-50^{\circ} \mathrm{N}$ & $51^{\circ}-53^{\circ} \mathrm{W}$ & 183 & 10 & 45,000 \\
\hline 13-24 Aug & $48^{\circ}-50^{\circ} \mathrm{N}$ & $49^{\circ}-51^{\circ} \mathrm{W}$ & $146-183$ & 1 & 59,000 \\
\hline 18-29 Aug & $48^{\circ}-50^{\circ} \mathrm{N}$ & $51^{\circ}-53^{\circ} \mathrm{W}$ & 183 & 4 & 45,000 \\
\hline 19-29 Aug & $48^{\circ}-50^{\circ} \mathrm{N}$ & $51^{\circ}-53^{\circ} \mathrm{W}$ & 192 & 7 & 42,000 \\
\hline 20-31 Aug & $48^{\circ}-50^{\circ} \mathrm{N}$ & $51^{\circ}-53^{\circ} \mathrm{W}$ & $179-183$ & 3 & 12,000 \\
\hline 20-31 Aug & $47^{\circ}-48^{\circ} \mathrm{N}$ & $51^{\circ}-53^{\circ} \mathrm{W}$ & $174-192$ & 9 & 45,000 \\
\hline 30 Aug-8 Sep & $48^{\circ}-50^{\circ} \mathrm{N}$ & $51^{\circ}-53^{\circ} \mathrm{W}$ & $165-174$ & 6 & 11,000 \\
\hline
\end{tabular}

TABLE 6. Numbers of vertebrae in spotted wolffish from various areas of the Northwest Atlantic, $1950-67$. $(\mathrm{OB}+2 \mathrm{GH}$ includes Ungava Bay; $\mathrm{SE}=$ standard error; $95 \%$ limits $=95 \%$ confidence interval. $)$

\begin{tabular}{lccccccc}
\hline $\begin{array}{c}\text { NAFO } \\
\text { Div. } \\
\text { (Fig. 1) }\end{array}$ & $\begin{array}{c}\text { Years } \\
\text { of } \\
\text { sampling }\end{array}$ & $\begin{array}{c}\text { No. } \\
\text { of } \\
\text { fish }\end{array}$ & $\begin{array}{c}\text { Length } \\
\text { range } \\
(\mathrm{cm})\end{array}$ & & & & \multicolumn{2}{c}{ Vertebral numbers } \\
\hline 1ABC & 1965 & 12 & $21-100$ & 77.33 & 0.28 & $76.71-77.96$ & $76-79$ \\
OB+2GH & $1959-64$ & 32 & $30-107$ & 77.69 & 0.13 & $77.42-77.95$ & $77-79$ \\
2Jn & $1950-64$ & 127 & $30-106$ & 77.72 & 0.08 & $77.57-77.87$ & $76-80$ \\
2Js+3K & $1950-64$ & 193 & $35-110$ & 77.66 & 0.05 & $77.56-77.77$ & $75-79$ \\
3L & $1950-54$ & 195 & $29-114$ & 77.63 & 0.06 & $77.52-77.74$ & $75-79$ \\
3M & $1955-64$ & 22 & $25-81$ & 77.27 & 0.15 & $76.96-77.59$ & $76-79$ \\
3NOP & $1950-67$ & 88 & $27-120$ & 77.65 & 0.09 & $77.47-77.83$ & $74-80$ \\
4RSVW & $1960-67$ & 15 & $26-116$ & 77.53 & 0.17 & $77.18-77.89$ & $76-78$ \\
Overall & $1950-67$ & 684 & $21-120$ & 77.64 & 0.03 & $77.58-77.70$ & $74-80$ \\
\hline
\end{tabular}


placed in table 7 of the translation. It is assumed also that the Barents Sea sample of $A$. latifrons ( $=A$. denticulatus) in table 7 of the translation of Barsukov's (1959) paper is actually A. minor. This sample of 33 specimens had a vertebral average of 77.9 (range 76-79). Later in his text, in his description of $A$. minor, Barsukov gives the range of vertebral number for this species as 76-79. Beese and Kändler (1969), for 23 and 42 spotted wolffish from the Barents Sea and the Iceland-Greenland region, reported vertebral means and standard errors of $78.13 \pm 0.13$ and $77.42 \pm 0.11$ respectively and a vertebral range of $76-79$ for the combined samples. Beese and Kändler's (1969) vertebral mean from the Barents Sea was significantly higher than their mean for the Iceland-Greenland region and the mean for the Northwest Atlantic in this paper. However, the mean of Lühmann's (1954) sample from southwestern Iceland was similar to that of Beese and Kändler from the Barents Sea. The difference between Beese and Kändler's mean for the IcelandGreenland region and that for the Northwest Atlantic approaches significance, overlapping slightly at $95 \%$ confidence limits of 77.20-77.64 and 77.58-77.70 respectively, but the range of years during which the Northwest Atlantic data were collected weakens the comparison. Although Lühmann (1954) provided no detailed data for his vertebral mean of 78.16 for southwestern Iceland, his number and range indicate that the standard error should be close to that of Beese and Kändler (1969) for the Iceland-Greenland region $( \pm 0.11)$. If so, the mean (78.16) differs significantly from that for the Northwest Atlantic.

Dorsal fin-ray numbers. The overall dorsal fin-ray frequency for 40 spotted wolffish from the Northwest lantic was $74(3), 75(7), 76(21), 77(9)$, with mean and standard error of $75.90 \pm 0.13$. The mean and range of dorsal fin-ray numbers in 45 spotted wolffish from southwestern Iceland (Lühmann, 1954) were 75.58 and 74-78 respectively. Barsukov's (1959, table 7) sample of 31 specimens of $A$. latifrons ( $A$. denticulatus), but presumably $A$. minor (note previous discussion of vertebral numbers), from the Barents Sea had a mean and standard error of $76.45 \pm 0.14$ dorsal fin-rays (range 75-78). The same sample of dorsal fin-rays is named $A$. minor in table 22 of the translation of Barsukov's (1959) paper. The dorsal fin-ray means and standard errors of 23 A. minor from the Barents Sea and 42 from the Iceland-Greenland region (Beese and Kändler, 1969) were $76.69 \pm 0.13$ and $75.85 \pm 0.13$ respectively, the combined range of both samples being $74-78$.

The two Barents Sea means are not significantly different, but the remaining three means including that from the Northwest Atlantic are significantly lower (estimating that Lühmann's southwestern Iceland mean from its comparison of numbers and range with the Iceland-Greenland sample should have a standard error of about \pm 0.13$)$. The Northwest Atlantic mean is not significantly different from the Iceland-Greenland and the southwestern Iceland means (assuming \pm 0.13 for the standard error of the latter.

Correlation of dorsal fin-rays and vertebral numbers. The geometric mean functional regression equation (Ricker, 1973, 1975) best describes the joint variation of the small sample of dorsal fin-rays and vertebral numbers in the same fish. In a sample of 34 fish $(21-100 \mathrm{~cm}$ in length) there was a highly significant correlation ( $r=0.65$ ) between dorsal fin-ray numbers and vertebral numbers (Fig. 3).

\section{Stomach contents}

Of 74 stomachs of spotted wolffish examined, 41 $(55 \%)$ contained food. The observations included fish from West Greenland to the Scotian Shelf, but most of the stomachs with food (25) were from the Northeast Newfoundland Shelf and the Grand Bank, and only one was from south of the Laurentian Channel.

In the subset of stomachs for which food quantity was measured, echinoderms constituted the greatest volume $(52 \%)$, followed by fish $(23 \%)$ and crustaceans (16\%) (Table 7 ). In terms of percentage occurrence of food types in all fish with food, echinoderms were again most important, followed by molluscs and decapod crustaceans. The wolffish ranged in size from 32 to $119 \mathrm{~cm}$ ( 8 at $32-59 \mathrm{~cm}, 12$ at $60-89 \mathrm{~cm}$, and 21 at 90-119 cm). There was no obvious difference in food type with fish size, except that the five specimens which had consumed fish were large $(90-107 \mathrm{~cm})$. One

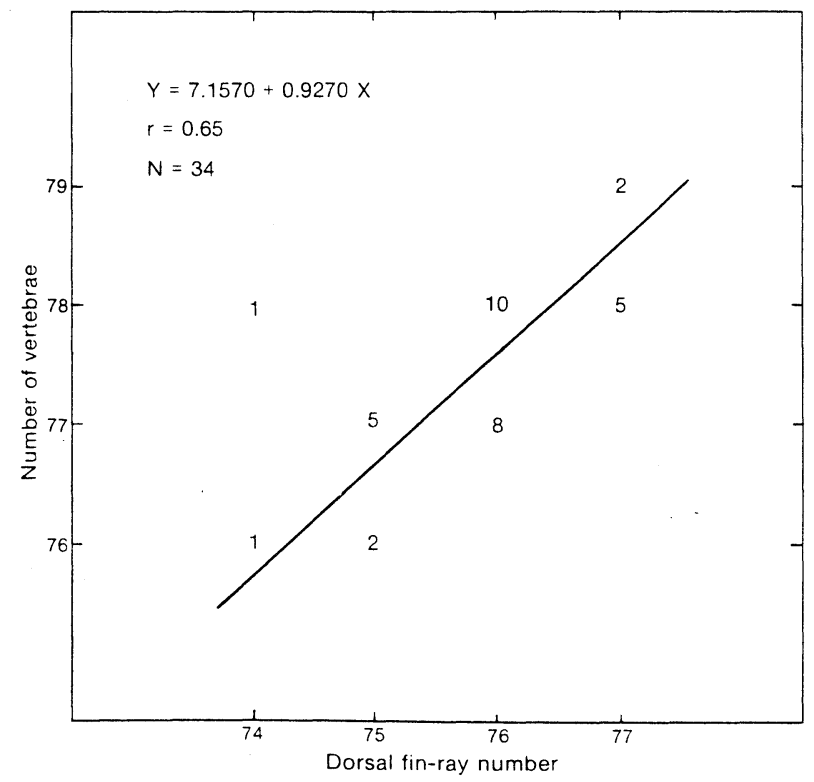

Fig. 3. Correlation of numbers of dorsal fin-rays and vertebrae in spotted wolffish from the Northwest Atlantic. (GM functional regression line is illustrated.) 
TABLE 7. Occurrence and volume of various food items in stomachs of spotted wolfifsh from the Northwest Atlantic, expressed as percent occurrence and percent by volume of food in stomachs containing food. (Volume measurements pertain to a subset of stomachs with food; + indicates $<0.1 \%$.)

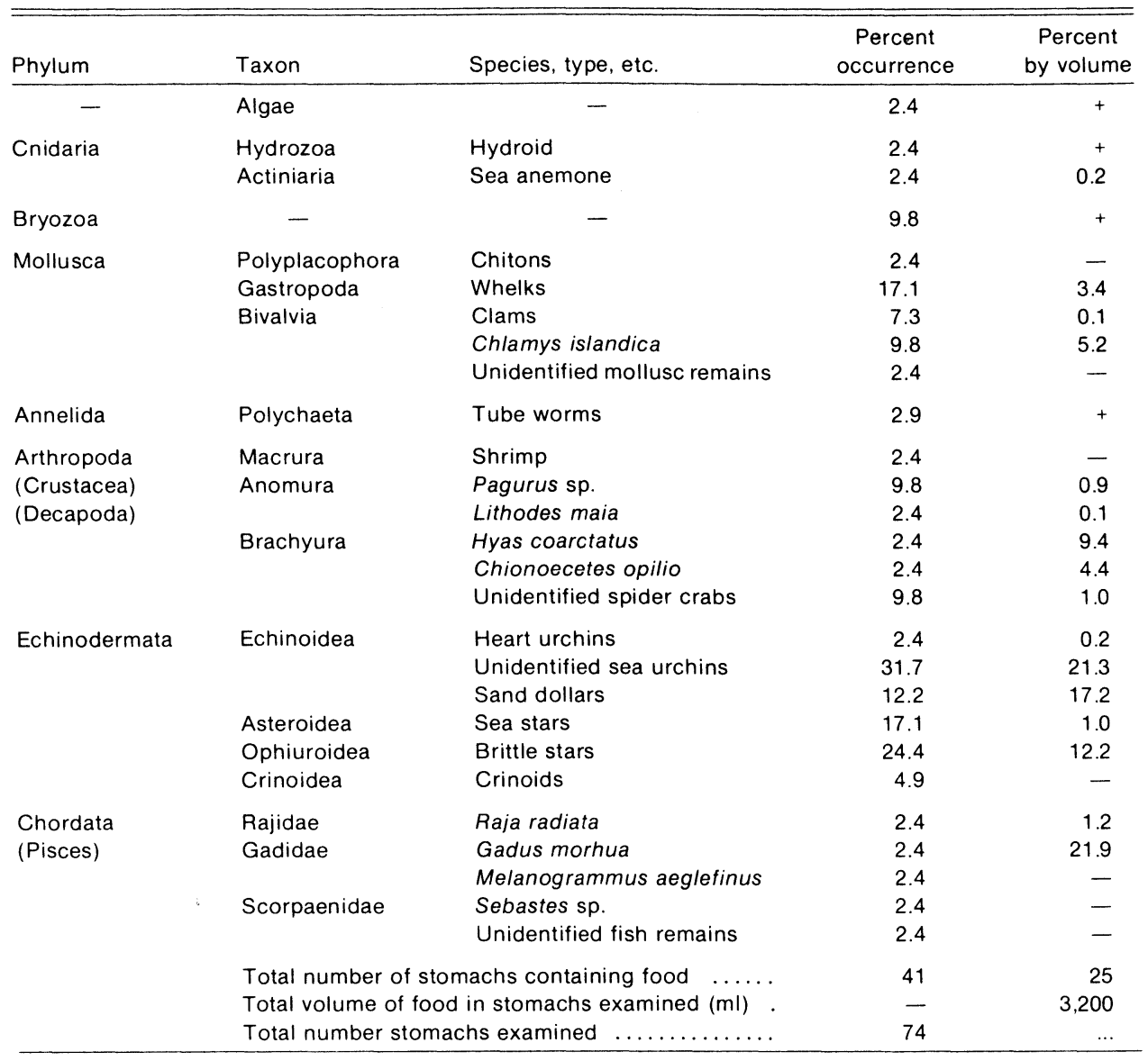

of these stomachs contained a 22-cm haddock and another contained a $35-\mathrm{cm}$ redfish, confirming that fish is probably an important component of the diet of large spotted wolffish. However, the diet overall was largely composed of hard-shelled animals. Among the echinoderms, the most important forms were sea urchins, sand dollars and brittle stars. The sand dollars in the stomachs were broken into pieces (about $1 \mathrm{~cm}^{2}$ in one instance and $2-4 \mathrm{~cm}^{2}$ in another), and the sea urchins were also crushed.

Barsukov (1959) noted the relative numbers of food organisms in the intestines of spotted wolffish, presumably from the Barents Sea. Echinoderms were most numerous, followed by molluscs, crustaceans and fishes. Albikovskaya (1983) studied the stomach contents of spotted wolffish of the LabradorNewfoundland region and found that echinoderms had both highest volume and frequency, with sand dollars, brittle stars and sea stars being most important. Gastropods and crabs were also important prey, and fish was an important component on Flemish Cap (Div. $3 \mathrm{M})$. Thus, previously-published information and the present study indicate that echinoderms constitute the dominant food type in the diet of spotted wolffish.

\section{Acknowledgements}

I am grateful to C. I. Barbour, E. M. LeGrow, and other techicians of the Northwest Atlantic Fisheries Centre for assistance in counting vertebrae and finrays, and to J. R. Burt and C. R. Rice for help in assembling the data.

\section{References}

ALBIKOVSKAYA, L. K. 1982. Distribution and abundance of Atlantic wolffish, spotted wolffish and northern wolffish in the Newfoundland area. NAFO Sci. Coun. Studies, 3: 29-32.

1983. Feeding characteristics of wolffishes in the Labrador-Newfoundland region. NAFO Sci. Coun. Studies, 6: 35-38.

BARSUKOV, V. V. 1959. The wolffish (Anarhichadidae). Tr. Zool. Inst. Acad. Sci. USSR: Fishes, 5(5): 173 p. (Transl. for Smithsonian Institute and National Science Foundation, Washington, D.C., by Indian National Scientific Documentation Centre, New Delhi, 1972).

BEESE, G., and R. KÄNDLER. 1969. Beiträge zur Biologie der drei nordatlantischen Katfischarten, Anarhichas lupus L., A. minor Olafs. und A. denticulatus Kr. Ber. Dtsch. Wiss. Komm. Meeresforsch., 20: 21-59. (Fish. Res. Board Can. 
Transl. Ser., No. 1811, 1971).

BIGELOW, H. B., and W. C. SCHROEDER. 1953. Fishes of the Gulf of Maine. Fish. Bull. U.S., 53: 577 p.

HANSEN, P. M. 1957. Spotted wolffish (Anarhichas minor). ICES Ann. Biol., 14: 40.

1958. Spotted wolffish (Anarhichas minor) and striped wolffish. Anarhichas lupus. ICES Ann. Biol.,13: 53.

KNIPOWITSCH, N. M. 1902. Ekspeditsiya dlya nauchnopromyslovykh issledovanii u beregov Murmana (Expedition for scientific-commercial studies on the Murman Coast), I, $605 \mathrm{p}$.

KOHLER, A. C. 1959. The growth, length-weight relationship and maturity of haddock (Melanogrammus aeglefinus L.) from the region of Lockeport, N.S. J. Fish. Res. Board Can., 17: 41-60.

LÜHMANN, M. 1954. Über intermediäre Formen zwischen Anarhichas minor Olafs. und A. Iupus L. (Teleostei). Ber. Dtsch. Wiss. Komm. Meeresforsch., 13: 310-326. (Fish. Res. Board Can. Transl. Ser., No. 1812, 1971).

LUNDBECK, J. 1937. Biologisch-statistische Untersuchungen über die deutsche Hochseefischerei. I. Die Zusammensetzung der Anlandungen. Ber. Dtsch. Wiss. Komm. Meeresforsch., N.F. 8: 37-129.

1952. Biologisch-statistische Untersuchungen über die deutsche Hochseefischerei. III. Das Körpergewicht and das Längen-Gewichts-Verhältnis bei den Nutzfischen. Ber. Dtsch. Wiss. Komm. Meeresforsch., N.F. 12: 316-429.
MCKENZIE, R. A., and R. E. S. HOMANS. 1938. Rare and interesting fishes and salps in the Bay of Fundy and off Nova Scotia. Proc. N.S. Inst. Sci., 19: 277-281.

$\varnothing$ STVEDT, O. J. 1963. On the life history of the spotted catfish (Anarhichas minor Olafsen). Fiskeridir. Skr. (Havunders.) 13: 54-72.

RICKER, W. E. 1973. Linear regressions in fishery research. J. Fish. Res. Board Can., 30: 409-434.

1975. Computation and interpretation of biological statistics of fish populations. Bull. Fish. Res. Board Can., 191: $382 \mathrm{p}$.

SCOTT, J. S. 1982. Depth, temperatures, and salinity preference of common fishes of the Scotian Shelf. J. Northw. Atl. Fish. Sci., 3: 29-39.

SNEDECOR, G. W., and W. G. COCHRAN. 1980. Statistical methods. (7th edition), lowa State Univ. Press, Ames, lowa, $507 \mathrm{p}$.

TEMPLEMAN, W. 1984. Vertebral and dorsal fin-ray numbers in Atlantic wolffish (Anarhichas lupus) of the Northwest Atlantic. J. Northw. Atl. Fish. Sci., 5: 207-212.

1985. Stomach contents of Atlantic wolffish (Anarhichas lupus) from the Northwest Atlantic. NAFO Sci. Coun. Studies, 8: 49-51.

1986. Some biological aspects of Atlantic wolffish (Anarhichas lupus) in the Northwest Atlantic. J. Northw. Atl. Fish. Sci., 7: this volume, p. 57-65.

TEMPLEMAN, W., and A. M. FLEMING. 1956. The Bonavista longlining experiment, 1950-1953. Bull. Fish. Res. Board Can., 109: $55 \mathrm{p}$. 
